\title{
Effects of Job Satisfaction on Job Performance and Occupational Commitment
}

\author{
Ismail Bakan', Tuba Buyukbese ${ }^{21}$, Burcu Ersahan ${ }^{1} \&$ Buket Sezer ${ }^{1}$ \\ ${ }^{1}$ Faculty of Economic and Administrative Sciences, Kahramanmaras Sutcu Imam \\ University, Kahramanmaras, Turkey \\ ${ }^{2}$ Faculty of Economic, Administrative, and Social Sciences, Hasan Kalyoncu University/ \\ School of Business and Social Sciences, Gaziantep, Turkey
}

\begin{abstract}
The paper aims to examine the effect of job satisfaction on the levels of job performance and occupational commitment among academicians in the universities. A structured questionnaire was used as an instrument for data collection, with academic staff in the Kahramanmaras Sutcu Imam University as respondents. The results of regression analysis indicated that job satisfaction has a positive impact on job performance and occupational commitment. Job satisfaction explains the 36.7 percent of job performance, and 48.0 percent of occupational commitment of academic staff. Additionally, occupational commitment has also a positive impact on job performance of academicians and explains 28.7 percent of their job performance. Academic administrators can provide a suitable organizational climate to increase the satisfaction level and thus, occupational commitment and job performance of the academic staff will increase. The results and recommendations in the paper will be of interest to all academic administrators and staff, not only for the Kahramanmaras Sutcu Imam University but also for the academic administrators in all universities.
\end{abstract}

KEYWORDS: Academicians, Job satisfaction, Job performance, Occupational Commitment.

\section{Council for Innovative Research}

Peer Review Research Publishing System

Journal: International Journal of Management \& Information Technology

Vol. 9, No. 1

editor@cirworld.com

www.cirworld.com, member.cirworld.com

\footnotetext{
${ }^{1}$ Correspondence: Tuba Buyukbese, Faculty of Economic Administrative, and Social Sciences, HasanKalyoncu University, School of Business and Social Sciences, Gaziantep, Turkey. Tel: 034221180 80. E-mail: tbuyukbese@yahoo.com
} 


\section{INTRODUCTION}

Job satisfaction is an important research subject, not only for behavioral scientists, but also for managers and organizations, for more than half a century. Job satisfaction is still important for organizations because employees, who are satisfied with their job, may display high effort in their jobs. Broome and his colleagues (2009) explained this interest in job satisfaction with its links to job-related behaviors, including performance (Christen, lyer \& Soberman, 2006; Iaffaldano \& Muchinsky, 1985; Ostroff, 1992;Petty, McGee \& Cavender,1984; Riketta, 2008; Schleicher, Watt \& Greguras, 2004) and employee turnover and turnover intentions (Smith, 1992). Previous studies also found the relationships between job satisfaction and many variables such as motivation, organizational commitment, stress, salary, promotion, role conflict, distributive and procedural justice, role ambiguity, autonomy, workload, leadership style, educational level, emotional intelligence (Agho, Mueller \& Price, 1993; Chu, Hsu, Price\& Lee, 2003; Dogan, 2009; Kafetsios \& Zampetakis, 2008; Ross \& Reskin, 1992; Stordeur D'Hoore\&Vanderberghe, 2001). As a consequence, interest in job satisfaction will continue in organizations.

Job satisfaction has been defined in different ways by many researchers and authors. The most widely used definitions found in the literature are as follows:

- A pleasurable or positive emotional state resulting from an appraisal of one's job or job experiences (Locke, 1976).

- One's affective reactions to his/her job (Hackman \& Oldham, 1975).

- A positive (or negative) evaluative judgment one makes about one's job or job situation (Weiss, 2002).

- Feelings or affective responses to facets of the situation (Smith, Kendall \&Hulin, 1969).

According to some authors (Locke, Hackman, Oldman) job satisfaction is one's "emotional reactions" to one's job. H.M. Weiss (2002) argued that the three constructs of an evaluative judgment regarding jobs, affective experiences at work, and beliefs about jobs need to be distinguished. To Weiss, job satisfaction is not an affective reaction, but rather an attitude that is an evaluative judgment involving objects (Lim, 2008). Ilies and Judge (2004) joined these definitions and defined job satisfaction as "an attitudinal concept reflecting one's evaluation about one's job, as well as an emotional reaction to it". There are different job satisfaction instruments used by the researchers in the literature based on the different definitions. The most popular job satisfaction instruments are Smith et al.(1969) Job Descriptive Index; D.J.Weiss, Dawis, England, and Lofquist's (1967) Minnesota Satisfaction Questionnaire; and Spector's (1985) Job Satisfaction Survey (JSS). JSS is a 36 item, nine-facet scale to assess employee attitudes about the job and aspects of the job. As a job satisfaction scale, JSS was used in this study.

Most of employees have a dynamic and multidirectional career path and more occupational opportunities than did their predecessors in earlier generations (Bakan, Ersahan, Buyukbese, \& Kefe,2012). Commitment is more important for managers and organizations than ever. Hence, organizational commitment is "the relative strength of an individual's identification with and involvement in a particular organization" (Mowday, Steers \& Porter, 1979). Similarly, occupational commitment is generally defined as the strength of an individual's identification with and involvement in an occupation (Aranya, Pollock\&Amernic, 1981). Lodahl and Kejner(1965) described the occupational commitment as "the degree to which a person's work performance affects his self-esteem".

Mowday et al. (1979) stated that committed individuals believe in and accept organizational goals and values, and are willing to remain within their organizations, and willing to provide considerable effort on their behalf. Therefore, commitment reflects the psychological bond that ties the employee to the organization (Raab \& McCain, 2002). Job satisfaction is an antecedent variable for organizational commitment (Mowday et al., 1982). A number of studies found that job satisfaction positively correlates with organizational commitment (Cohrs, Abele \& Dette, 2006; Rayton, 2006; Schwepker, 2001; Yang \& Chang, 2007; Martin \& Bennett, 1996; Smith, 1996; Knoop, 1995; Kirsch, 1990; Almeer 1995). Other researchers have also found that organizational commitment and job performance are positively correlated (Babin\& Boles, 1996; Baugh \& Roberts, 1994; Ward \& Davis, 1995; Chen, Silverthorne \& Hung, 2006). On the other hand, Mathieu and Zajac (1990) concluded that commitment has relatively little direct influence on performance in most cases in their meta-analysis study (Chen et al., 2006).

Although there are several studies examining relationship between job satisfaction and organizational commitment, or job satisfaction and job performance, this study investigates the impact of job satisfaction on both occupational commitment and job performance of academic staff. Additionally our study explores the relationship between occupational commitment and job performance. The proposed hypotheses and a model were defined in the following section.

\section{THE RESEARCH MODEL AND HYPOTHESES}

"Academic staff has been regarded as a key factor and has an important role to play in educational settings. They have a crucial role in good learning outcomes, in training and socializing students. Their satisfaction within their jobs increases motivation and morale to contribute to the system and their involvement leads to better decisions" (Amazt \& Idris, 2011). Academic staff satisfaction is considered as a very important resource for achieving high performance and strong commitment. Empirical studies have illustrated that employees' satisfaction from their job is a critical component of work-related behaviors and can impact their job performance. Although a number of studies have considered job satisfaction and related it to the other variables, only our study has examined the impact of job 
satisfaction on occupational commitment of academic staff. This study also investigated the impacts of occupational commitment and job satisfaction on job performance.

Based on the past researches presented in the literature review, following hypotheses were proposed and a model was developed.

H1: There is a positive relationship between job satisfaction and occupational commitment.

H2: There is a positive relationship between job satisfaction and job performance.

H3: There is a positive relationship between occupational commitment and job performance.

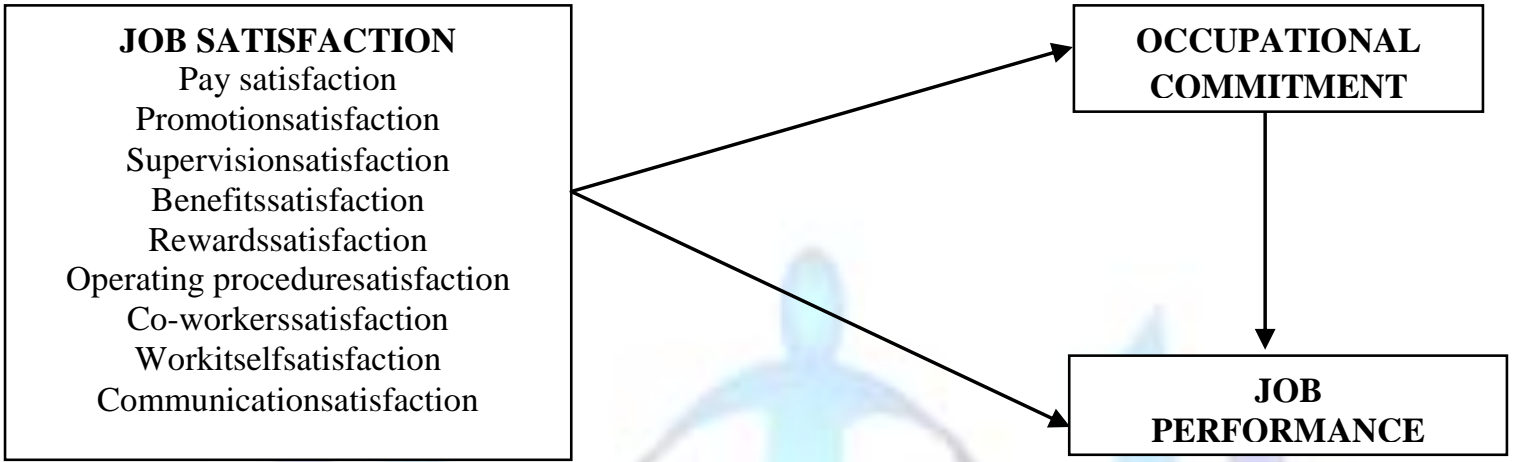

Figure 1. The model of job satisfaction, occupational commitment, and job performance

The model postulates the relationships between job satisfaction, occupational commitment, and job performance (Figure 1). According to this model, job satisfaction has a positive impact on occupational commitment and job performance of academicians. Additionally occupational commitment also has a positive impact on job performance.

\section{AIM OF THE STUDY}

In the literature, there are several studies, conducted examining the relationships of job satisfaction and different organizational and work related variables such as job performance, commitment, employee relations, turnover intention, productivity, absenteeism, etc. But there are a few studies related to job satisfaction, job performance, and occupational commitment among academicians. The major question addressed in this study is: What was the relative impact of job satisfaction, upon the occupational commitment and job performance of academic staff? This paper also aims to investigate;

- The relationship between job satisfaction of academic staff and their occupational commitment;

- Relationship between job satisfaction of academic staff and their job performance;

- Relationship between occupational commitment of academic staff and their job performance.

\section{RESEARCH METHODOLOGY}

To answer this question and verify the proposed hypotheses, and test the whole research model proposed, an empirical study was conducted in Kahramanmaras Sutcu Imam University, Turkey. The questionnaire method was employed for data collection and the SPSS software package was used to analyze the quantitative data from the empirical survey. The questionnaire comprises of two parts. Demographic features of participants have been included in the first part, and in the second part there are total of 54 questions about job satisfaction, occupational commitment and job performance. All of the constructs used in this study were drawn from existing literature and were translated and adapted for the context of this research. Subjects' responses were coded using five point Likert type scales, in which 5 indicated "strongly agree" and 1 indicated "strongly disagree", in the second part of the questionnaire.

The job satisfaction was adopted from Job Satisfaction Survey (JSS) developed by Spector (1985). It consists of 36 items, which measure nine aspects of a job: Pay, promotion, supervision, benefits, rewards, operating procedures coworkers, work itself, communications (each aspect has four items).

Occupational commitment was assessed via a 15 item measure developed by Mowday et al. (1979). The 3 item job performance scale was adopted from Goodwin, Groth, and Frenkel's (2011) study.

Table 1. Reliability Analyses

\begin{tabular}{lllll}
\hline & N & $\bar{x}$ & Std. Dev. & Cronbach Alfa \\
\hline Jobsatisfaction & 130 & 3.7385 & 0.67701 & 0.947 \\
Occupationalcommitment & 130 & 3.8821 & 0.64396 & 0.931 \\
Jobperformance & 130 & 3.8923 & 0.69172 & 0.866 \\
\hline
\end{tabular}


The Cronbach Alpha is calculated to see the internal consistency of the items. If Cronbach Alpha internal consistency is between 0.80 and 1.00 , it means that the scale is highly reliable. Reliability analyses were conducted on these items and revealed very high Cronbach alpha scores as shown in Table 1.

At the research time, there was a total of 892 academic staff working in Kahramanmaras Sutcu Imam University. Questionnaires were distributed to all academicians in every department at this university, and 130 usable questionnaires were obtained which is about 14.57 percent rate of return. Descriptive statistical analysis including frequencies and percentages was used to present the main characteristics of the sample. When asked to specify respondents' demographic characteristics, 69.6 percent of them were male and 30.4 percent were female. It was found that 60 percent of the respondents were married, while 40 percent single. There were two main specialization groups of respondents in which 47.3 percent were studying science, and 52.7 percent of them were studying social studies. Data also shows that about 52 percent of respondents had been working as an academician in this university for 5 years or less and 48 percent of respondents had their experience as an academician for more than 5 years. Based on the respondents' educational attainment level, the majority, 56.2 percent of lecturers hold a PhD degree, about 36.9 percent had obtained master degree. The demographic data also indicates that 9.2 percent of the respondents were Professor, 11.5 percent Associate Professor, 25.4 percent Assistant Professor, 37.7 percent Research Assistant, and the remaining 16.1 percent were Instructor or Specialist. 18.3 percent of the research participants had administrative position.

Table 2. Participants' demographic characteristics

\begin{tabular}{|c|c|c|c|c|c|}
\hline & $\begin{array}{l}\text { Frequency } \\
\text { (f) }\end{array}$ & $\begin{array}{l}\text { Percentage } \\
(\%)\end{array}$ & & $\begin{array}{l}\text { Frequency } \\
\text { (f) }\end{array}$ & $\begin{array}{l}\text { Percentage } \\
(\%)\end{array}$ \\
\hline Gender & & & Age & & \\
\hline Female & 38 & 30,4 & Less than 26 & 19 & 15,0 \\
\hline Male & 87 & 69,6 & $26-30$ & 32 & 25,2 \\
\hline Marital Status & & & $31-45$ & 28 & 22,1 \\
\hline Married & 78 & 60,0 & $46-50$ & 27 & 21,3 \\
\hline Single & 52 & 40,0 & More than 50 & 13 & 16,5 \\
\hline Educational Qu & fication & & Tenure & & \\
\hline Undergraduate & 9 & 6,9 & $0-5$ Years & 66 & 52,0 \\
\hline Masters & 48 & 36,9 & 6-10 Yea & 15 & 11,8 \\
\hline Doctorate & 73 & 56,2 & $11-15 Y$ & 13 & 10,2 \\
\hline Academic Title & & & More than 15 & 33 & 26,0 \\
\hline Prof. & 12 & 9,2 & Area of Specialization & & \\
\hline Asc. Prof. & 15 & 11,5 & Science & 61 & 47,3 \\
\hline Ass. Prof. & 33 & 25,4 & Social studies & 68 & 52,7 \\
\hline Instructor & 12 & 9,2 & Administrative Position & & \\
\hline Res. Ass. & 49 & 37,7 & Yes & Yes & 18,3 \\
\hline Specialist & 9 & 6,9 & No & No & 81,7 \\
\hline
\end{tabular}


The statistical methods used in this research include the Pearson Correlation as well as multiple regression analysis. For the purposes of determining whether a statistically significant relationship exists between job satisfaction and occupational commitment, job satisfaction and job performance, occupational commitment and job performance the Pearson Correlation was used. The Pearson correlations reveal that there are significant correlations between job satisfaction and occupational commitment $(r=0.550, p<0.01)$, job satisfaction and job performance $(r=0.356, p<$ $0.01)$, and between occupational commitment and job performance $(r=0.541, p<0.01)$.

Table 3. Pearson Correlation

\begin{tabular}{llll}
\hline Variables & $\begin{array}{l}\text { Job } \\
\text { Satisfaction }\end{array}$ & $\begin{array}{l}\text { Occupational } \\
\text { Commitment }\end{array}$ & $\begin{array}{l}\text { Job } \\
\text { Performance }\end{array}$ \\
\hline Job Satisfaction & $\mathrm{x}$ & & \\
& $.550^{\star *}$ & $\mathrm{x}$ \\
Occupational Commitment & .000 & & \\
& & $.541^{\star *}$ & $\mathrm{x}$ \\
Job Performance & $.356^{\star \star}$ & .000 &
\end{tabular}

Note: ${ }^{*}$ Significant at the 0.01 level (two-tailed)

\section{THE RESULTS OF REGRESSION ANALYSIS}

The linear regression analysis has been conducted in order to investigate the impact of independent variable on the dependent variables. Thus, it is aimed to test the research hypotheses and the theoretical model.

\begin{tabular}{lllll}
\hline Independent variables & Std.Error & Beta & $\mathrm{t}$ & Sig \\
\hline (Constant) & 0.269 & 5.061 & 0.000 \\
Pay satisfaction & 0.064 & 0.023 & 0.299 & 0.765 \\
Promotion satisfaction & 0.052 & 0.158 & 1.976 & 0.050 \\
Supervision satisfaction & 0.051 & 0.148 & 1.717 & 0.089 \\
Benefits satisfaction & 0.067 & -0.056 & -0.630 & 0.530 \\
Rewards satisfaction & 0.086 & 0.085 & 0.778 & 0.438 \\
Operating procedure satisfaction & 0.079 & -0.159 & -2.007 & 0.047 \\
Co-workers satisfaction & 0.080 & -0.007 & -0.076 & 0.939 \\
Work itself satisfaction & 0.071 & 0.602 & 7.753 & 0.000 \\
Communication satisfaction & 0.066 & 0.009 & 0.092 & 0.927 \\
\hline$R^{2}=.518$ & & & & \\
Adjust. $R^{2}=.480$ & & & & \\
F=13.824 & & & \\
Sig=.000 & & & \\
\hline
\end{tabular}

Table 4. Results of Regression Analysis of the Effect of Job Satisfaction on Occupational Commitment

The influence of academicians' job satisfaction on their occupational commitment was investigated with regression analysis. Table 4 depicts the results of regression analysis, regressing the job satisfaction variables against occupational commitment. Six out of nine variables of job satisfaction were not significant in explaining occupational commitment except for work itself satisfaction, operating procedure satisfaction, and promotion satisfaction (Table 4). An examination of the parameter estimates (especially the standardized beta values) that work itself satisfaction $($ Beta $=0.602 ; p<0.01)$ have the greatest impact on occupational commitment. Operating procedure satisfaction (Beta $=0.159 ; p<0.01)$, and promotion satisfaction (Beta=0.158; $p \leq 0.05)$, was significant but less important in explaining occupational commitment of academicians. Results indicate that the adjusted R-Squared value of 0.480 indicates that $48 \%$ of the variance in occupational commitment can be accounted by these job satisfaction variables. This study provides empirical evidence that job satisfaction is related with occupational commitment. The findings show that $\mathrm{H}_{1}$ "There is a positive relationship between job satisfaction and occupational commitment" is supported. 
Table 5.results of regression analysis of the effect of job satisfaction on job performance

\begin{tabular}{|c|c|c|c|c|}
\hline Independent variables & Std.Error & Beta & $\mathrm{t}$ & Sig \\
\hline (Constant) & 0.285 & & 8.100 & 0.000 \\
\hline Pay satisfaction & 0.016 & 0.016 & 0.191 & 0.849 \\
\hline Promotion satisfaction & 0.102 & 0.102 & 1.149 & 0.253 \\
\hline Supervision satisfaction & 0.194 & 0.194 & 2.050 & 0.043 \\
\hline Benefits satisfaction & -0.074 & -0.074 & -0.758 & 0.450 \\
\hline Rewards satisfaction & -0.290 & -0.290 & -2.429 & 0.017 \\
\hline Operating procedure satisfaction & -0.092 & -0.092 & -1.057 & 0.293 \\
\hline Co-workers satisfaction & -0.020 & -0.020 & -0.190 & 0.850 \\
\hline Work itself satisfaction & 0.649 & 0.649 & 7.631 & 0.000 \\
\hline Communication satisfaction & 0.053 & 0.053 & 0.493 & 0.623 \\
\hline \multicolumn{5}{|l|}{$\mathrm{R}^{2}=.412$} \\
\hline \multicolumn{5}{|l|}{ Adjust. $R^{2}=.367$} \\
\hline$F=9.114$ & & & & \\
\hline Sig $=.000$ & & & & \\
\hline
\end{tabular}

A significant relation is observed between job satisfaction and job performance in the correlations analysis. In addition, regression analysis has been practiced in order to find out on what extend job satisfaction variables has an impact on job performance. As shown in Table 5 , the regression model also statistically significant. The overall F-statistic of 9.114 is significant at the 0.01 level $(F=9.114: p<0.01)$; the $\mathrm{R}^{2}$ (standardized R-square) value is 0.367 . This indicates that approximately $37 \%$ of the variance in job performance can be attributed to the independent variables entered into

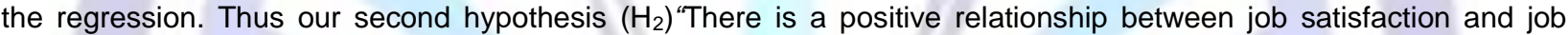
performance" is supported. As shown in Table 5, only three independent variables of job satisfaction; work itself satisfaction, rewards satisfaction, and supervision satisfaction are significant in explaining job performance of academicians. Work itself has the highest beta score $(B e t a=0.649)$, so it is the most effective variable on explaining job performance. But the result shows no significance relationship between pay satisfaction, promotion satisfaction, benefits satisfaction, operating procedure satisfaction, co-workers satisfaction, communication satisfaction, and occupational commitment.

Table 6. Results of regression analysis of the effect of occupational commitment on job performance

\begin{tabular}{lllll}
\hline Independent variables & Std.Error & Beta & t & Sig \\
\hline Occupational commitment & 0.72 & 0.541 & 7.219 & 0.000 \\
\hline
\end{tabular}

$\mathrm{R}^{2}=.293$

Adjust. $\mathrm{R}^{2}=.287$

$F=52.109$

$\operatorname{Sig}=.000$

Further investigation was conducted to find out the effect of occupational commitment on job performance of academic staff. The regression model is significant $(F=52.109: p<0,01)$; it explains approximately $29 \%$ of the job performance of respondents. This study provides empirical evidence that occupational commitment is related with job 
performance. The findings show that our last hypothesis $\mathrm{H}_{3}$ "There is a positive relationship between occupational commitment and job performance" is supported.

\section{CONCLUSION}

Work is an important aspect of employed individuals' life and individuals spend most of their time doing their job. As a result, their feelings about their jobs, or in another word their satisfaction from their job, influences many aspects of work such as efficiency, productivity, absenteeism, turnovers rates, and intention to quit (Baron, 1986; Maghradi, 1999; Togia, Koustelios, \& Nikolaos, 2004). The purpose of this study was to propose and test a model about the impacts of job satisfaction in universities.

Universities are one of the most important organizations in education and research, in today's rapidly changing, competitive environment. Universities provide education by academicians. As teaching does require a great deal of thoroughness and commitment (Ali \&Akhter, 2009), it is more important to have satisfied and committed staff to display high performance in their jobs.

The current study aimed to examine the effect of job satisfaction on the levels of job performance and occupational commitment among academicians in the universities. Job satisfaction scale has nine dimensions, called: Pay, promotion, supervision, benefits, rewards, operating procedures, coworkers, work itself, and communications. From these dimensions "work itself satisfaction" was the most effective factor both on occupational commitment and job performance of academicians. The results of regression analysis indicated that job satisfaction had a positive impact on job performance, and occupational commitment. Job satisfaction explains the 36.7 percent of job performance, and 48.0 percent of occupational commitment of academic staff. Additionally, occupational commitment has also a positive impact on job performance of academicians and explains 28.7 percent of their job performance.

Job satisfaction leads to several benefits for staff, such as reducing moral stress, create new thinking and innovation which lead them to high level, fresh mind good relationship, with co-workers, supervisor and employees etc. (Nimalathasan \& Brabete, 2010). The administrators' efforts to create, the best work environment for staff and positive feelings of attachment towards the organization, may increase the job performance of staff, as well as to overcome obstacles to effective performance.

\section{REFERENCES}

[1] Agho, A.O., Mueller, C.W.,\& Price, J.L. (1993).Determinants of employee job satisfaction: An emprical test of a causal mode. Human Relations, 46, 1007-1027.

[2] Almeer, A. (1995).The relationship between job stress, organizational commitment, performance, job satisfaction, and demographic factors. Journal of Public Administration, 35, 207-249.

[3] Amazt, I.H.,\&Idris, A.R. (2011).Lecturers' satisfaction towards university management \& decision-making styles in some Malaysian public universities. Procedia Social and Behavioral Sciences, 15, 3957-3970.

[4] Aranya, N., Pollock J.,\&Amernic, J. (1981).An examination of professional commitment in public accounting.AccountingOrgaizations and Society, 6(4), 271-280.

[5] Babin, B.J., \& Boles, J.S. (1996).The effects of perceived co-worker involvement and supervisor support on service provider role stress, performance, and job satisfaction. Journal of Retailing, 72(1), 57-75.

[6] Bakan, I., Ersahan, B., Buyukbese, T., \&Kefe, I. (2012).The research preferences and occupational commitment of academic staff.Paper presented at Cyprus International Conference on Educational Research (CY-ICER), 8-10 $\quad$ February, $\quad$ Cyprus. Retrieved from http://www.worldeducationcenter.eu/index.php/cyicer/cyicer2012/paper/view/10872

[7] Baron, R. (1986).Behavior in organizations. Newton, MA: Allyn and Bacon.

[8] Baugh, S.G.,\& Roberts, R.M. (1994).Professional and organizational commitment among engineer: Conflicting or complementary? IEEE Transactions on Engineering Management, 41( 2), 108-114.

[9] Broome, K.M., Knight, D.K., Edwards, J.R.,\& Flynn, P.M. (2009).Leadership, burnout, and job satisfaction in outpatient drug-free treatment programs. Journal of Substance Abuse Treatment, 37, 160-170.

[10] Chen, J.C., Silverthorne, C.,\& Hung, J.Y. (2006).Organization communication, job stress, organizational commitment, and job performance of accounting professionals in Taiwan and America.Leadership\& Organization Development Journal, 27(4), 242-249.

[11] Christen, M., lyer, G.,\&Soberman, D. (2006). Job satisfaction, job performance, and effort: A reexamination using agency theory. Journal of Marketing, 70(1), 137-150.

[12] Chu, C.I, Hsu, H.M., Price, J.L.,\& Lee, J.Y. (2003).Job satisfaction of hospital nurses: An emprical test of a causal model in Taiwan. International Nursing Review, 50, 176-182.

[13] Cohrs, J.C., Abele, A.E.,\&Dette, D.A. (2006).Integrating situational and dispositional determinants of job satisfaction: Findings from three samples of professionals. The Journal of Psychology, 140 (4), 363-395. 
[14] Dogan, H. (2009). A comparative study for employee job satisfaction in Aydin municipality and Nazillimunicipality.Ege Academic Review, 9(2), 423-433.

[15] Eyupoglu, S.Z., \& Saner, T. (2009).The relationship between job satisfaction and academic rank: A study of academicians in Northern Cyprus.Procedia-Social and Behavioral Sciences, 1(1), 686-691.

[16] Hackman, J.R., \& Oldham, G.R. (1975).Development of the job diagnostic survey.Journal of Applied Psychology, 60(2), 159-170.

[17] laffaldano, M.T.,\&Muchinsky, P.M. (1985).Job satisfaction and job performance: A metaanalysis. Psychological Bulletin, 97(2), 251-273.

[18] Ilies, R.,\& Judge, T.A. (2004).An experience-sampling measure of job satisfaction and its relationships with affectivity, mood atwork, job beliefs, and general job satisfaction.European Journal of Work and Organizational Psychology, 13(3), 367-389.

[19] Kafetsios, K.,\&Zampetakis, L.A. (2008).Emotional intelligence and job satisfaction: Testing the mediatory role of positive and negative affect at work. Personality and Individual Differences, 44, 712-722.

[20] Kirsch, J. (1990).Staff development opportunity and nurses job satisfaction, organizational commitment, and intent to remain in the organization. J Nurs Staff Dev, 279-282.

[21] Knoop, R. (1995). Relationships among job involvement, job satisfaction and organizational commitment for nurses. Journal of Psychology, 29, 643-649.

[22] Lim, S. (2008).Job satisfaction of information technology workers in academic libraries. Library\& Information Science Research, 30, 115-121.

[23] Locke, E.A. (1976). The nature and causes of job satisfaction. In M.D. Dunnette(Ed.), Handbook of industrial and organizational psychology (pp.1297-1349).Chicago: Rand McNally

[24] Maghradi, A. (1999). Assessing the effect of job satisfaction on managers. International Journal of VauleBased Management, 12, 1-12.

[25] Martin, C.L. \& Bennett, N. (1996).The role of justice judgments in explaining the relationship between job satisfaction and organization commitment. Group and Organization Management: Vol. 21 No. 1, pp. 84-104.

[26] Mathieu, J.E., \&Zajac, D.M. (1990).A review and meta-analysis of the antecedents, correlates, and consequences of organizational commitment. Psychological Bulletin, 108, 171-194.

[27] Mowday, R., Steers, R.M.,\& Porter, L.W. (1979). The measurement of organizational commitment. Journal of Vocational Behavior, 14(2), 224-247.

[28] MowdayR.,Porter L.\& Steers R. (1982). Employee Organization Linkages: The Psychology of Commitment, Absenteeism, and Turnover. New York: Academic Press.

[29] Nimalathasan, B.,\&Brabete, V. (2010).Job satisfaction and employees' work performance: A case study of people's bank in Jaffna Peninsula, Sri Lanka. Management and Marketing Journal, 8(1), 43-77.

[30] Ostroff, C. (1992). The relationship between satisfaction, attitudes, and performance: An organizational level analysis. Journal of Applied Psychology, 77(6), 963-974.

[31] Petty, M.M., McGee, G.W.,\&Cavender, J.W. (1984).A metaanalysis of the relationships between individual job satisfaction and individual performance.Academy of Management Review, 9(4), 712-721.

[32] Raab, C., \& Chen, S.L. (2002).Employee commitment and restaurant profitability. Journal of Human Resources in Hospitality \& Tourism, 1(3), 1-10.

[33] Rayton, B.A. (2006). Examining the interconnection of job satisfaction and organizational commitment: An application of the bivariate probitmodel. International Journal of Human Resource Management, 17(1), 139154.

[34] Riketta, M. (2008).The causal relation between job attitudes and performance: A meta-analysis of panel studies. Journal of Applied Psychology, 93, 472-481.

[35] Robyn, E., Goodwin, M.G.,\& Stephen J. F. (2011). Relationships between emotional labor, job performance, and turnover. Journal of Vocational Behavior, 79(2), 538-548.

[36] Ross, C.E.,\&Reskin, B.F. (1992).Education, control at work and job satisfaction.Social Science Research, 21(2), 134-148.

[37] Schleicher, D.J., Watt, J.D. \&Greguras, G.J. (2004).Reexamining the job satisfaction-performance relationship: The complexity of attitudes. Journal of Applied Psychology, 89(1), 165-177.

[38] Schwepker, C.H. (2001). Ethical climate's relationship to job satisfaction, organizational commitment and turnover intention in the salesforce. Journal of Business Research, 54(1), 39-52. 
[39] Smith, D. (1996). Increasing employee productivity, job satisfaction, and organizational commitment. Hospital\& Health Service Administration, 4, 160-174.

[40] Smith, P.C., Kendall, L.M., \&Hulin, C.L. (1969). The measurement of satisfaction in work and retirement. Chicago: Rand McNally.

[41] Smith, P.C. (1992). In pursuit of happiness: Why study general job satisfaction? (ed.C.J. Cranny, et al.,), Job satisfaction(pp.5-19). New York: Lexington

[42] Spector, P.E. (1985). Measurement of human service staff satisfaction: development of the job satisfaction survey (JSS). American Journal of Community Psychology, 13, 693-713.

[43] Stordeur, S., D'Hoore, W.,\&Vandenberghe, C. (2001).Leadership, organizational stress, and emotional exhaustion among hospital nursing staff. Journal of Advanced Nursing, 35(4), 533-542.

[44] Taskina, A., \&Akhter, I. (2009).Job satisfaction of faculty members in private universities-In context of Bangladesh. International Business Research, 2(4), 167-175.

[45] Togia, A., Koustelios, A.,\&Tsigilis, N. (2004).Job satisfaction among Greek academic librarians. Library\& Information Science Research, 26, 373-383.

[46] Ward, E.A., \& Davis, E. (1995).The effect of benefit satisfaction on organization commitment. Compensation\& Benefits Management, 11(3), 35-40.

[47] Weiss, D.J., Dawis, R.V., England, G.W.,\&Lofquist, L.H. (1967).Manual for the Minnesota Satisfaction Questionnaire (Minnesota Studies in Vocational Rehabilitation, No. 22).Industrial Relations Center, Minneapolis: University of Minnesota.

[48] Weiss, H.M. (2002). Deconstructing job satisfaction: Separating evaluation, belief, and affective experiences. Human Resources Management Review, 12(2), 1-22.

[49] Yang, F.H.,\& Chang, C.C. (2007).Emotional labour, job satisfaction and organisational commitment amongst clinical nurses: a questionnaire survey. International Journal of Nursing Studies, 45(6),879-887. 